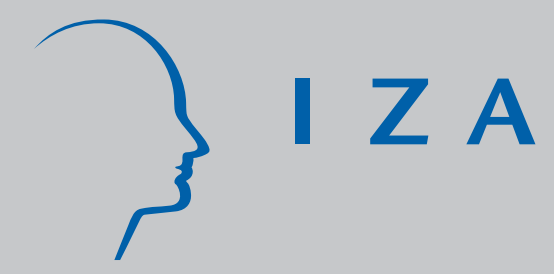

IZA DP No. 1567

Household Access to Microcredit and Child Work in Rural Malawi

Gautam Hazarika

Sudipta Sarangi

April 2005 


\title{
Household Access to Microcredit and Child Work in Rural Malawi
}

\author{
Gautam Hazarika \\ University of Texas at Brownsville \\ and IZA Bonn \\ Sudipta Sarangi \\ Louisiana State University
Discussion Paper No. 1567
April 2005 \\ IZA \\ P.O. Box 7240 \\ 53072 Bonn \\ Germany \\ Phone: +49-228-3894-0 \\ Fax: +49-228-3894-180 \\ Email: iza@iza.org
}

\begin{abstract}
Any opinions expressed here are those of the author(s) and not those of the institute. Research disseminated by IZA may include views on policy, but the institute itself takes no institutional policy positions.

The Institute for the Study of Labor (IZA) in Bonn is a local and virtual international research center and a place of communication between science, politics and business. IZA is an independent nonprofit company supported by Deutsche Post World Net. The center is associated with the University of Bonn and offers a stimulating research environment through its research networks, research support, and visitors and doctoral programs. IZA engages in (i) original and internationally competitive research in all fields of labor economics, (ii) development of policy concepts, and (iii) dissemination of research results and concepts to the interested public.
\end{abstract}

IZA Discussion Papers often represent preliminary work and are circulated to encourage discussion. Citation of such a paper should account for its provisional character. A revised version may be available directly from the author. 
IZA Discussion Paper No. 1567

April 2005

\section{ABSTRACT \\ Household Access to Microcredit and Child Work in Rural Malawi}

This paper examines the effect of household access to microcredit upon work by seven to eleven year old children in rural Malawi. Given that microcredit organizations foster household enterprises wherein much child labor is engaged, this paper aims to discover whether access to microcredit might increase work by children. It is found that household access to microcredit, measured in a novel manner as self-assessed credit limits at microcredit organizations, raises the probability of child work in households with sample mean values of land ownership and number of retail sales enterprises. It appears this is due to children having to take up more domestic chores as adults are busied in household enterprises following improved access to microcredit.

JEL Classification: J22

Keywords: child labor, microcredit

Corresponding author:

Gautam Hazarika

Department of Business Administration The University of Texas at Brownsville Brownsville, TX 78520

USA

Email: ghazarika@utb.edu 


\section{INTRODUCTION}

This study examines the effect of household access to microcredit upon children's propensity to work in rural Malawi and so conjoins the two topical subjects of microcredit and child labour. Given the growing role of microcredit in development financing and the increased disbursement of official aid via microcredit programs, an assessment of the effects of microcredit access upon child labour will be a useful contribution to research in the sustainability of development financing.

The International Labour Organization [ILO] considers child labour to be 'simply the single most important source of child exploitation and child abuse in the world today' [ILO, 1998, A]. As Binder and Scrogin [1999] put it, there are at least four reasons for the objectionability of child labour. First, child labour reduces children's current welfare. This is an especially pressing reason given children's vulnerability to exploitation. Second, by often reducing children's schooling, child labour may also lower children's future welfare. Third, reductions in children's schooling may slow the pace of national economic growth. Fourth, as argued by Basu and Van [1998], child labour may, by competing with adult labour, reduce adult wages, thereby increasing household dependence upon children's earnings, making for a vicious cycle of continued child labour.

The International Labour Organization estimates there are about 250 million 5-14 year old economically active children in developing countries, of whom at least 120 million are full-time workers $[I L O, 1998, A]$. These figures are certainly underestimates since they do not account for children's domestic chores such as cooking, cleaning, and childcare, relegated mostly to girls. By ILO estimates, Africa, with about 41 per cent of 5 to 14 year old children engaged in economic activity, has the highest incidence of child labour in the developing world [ILO, 1998, B]. Children's labour force participation rates are highest in Sub-Saharan Africa [ILO, 1998, B]. As regards Malawi in Southern Africa, the ILO estimates that 35.2 per cent of 10 to 14 year old Malawian children were working in 1995 [ILO, 1996, A]. Even though Malawian law prohibits the employment of persons less than 14 years of age, significant child labour may be found on tobacco and tea farms, subsistence farms, and in domestic service. 
In any case, labour laws may not be depended upon to stamp out child labour, consisting in the main of unpaid household work [ILO, 1996, B] usually beyond the ambit of legislation. It is now believed this type of work is not innocuous. For example, while the ILO acknowledges the need for distinction between "normal family obligations and work which gives rise to exploitation and abuse", it warns that "an emphasis on traditional practices over the potential hazards of work for children can result in ignoring the extent of the child labour problem" and that "what happens within the family context" may well fall within the purview of labour laws in the future [ILO, 1998, B]. Similarly, Nieuwenhuys [1994] writes, “the assumption that children's work, in the context of the peasant family, is morally neutral is preposterous." Detailed anthropological study in Kerala, India, leads Nieuwenhuys [1994] to conclude that work within the household is not any the less demanding or less important for families than market work, and there can be no presumption that poor parents are able to protect their children from excessive drudgery and exploitation. The predominance of unpaid household work among children's economic activities, apprehension that it too may be detrimental to children, and the difficulties of bringing household production within the purview of labour laws, have led to consideration of alternate means of combating child labour. For instance, the ILO holds that 'the single most effective way to stem the flow of school-age children into abusive forms of employment is to extend and improve schooling so that it will attract and retain them' [ILO, 1998, A]. Another such measure gaining currency is improvement in poor households' access to credit.

While child labour is widely held to stem from poverty, Baland and Robinson [2000] take the nuanced view that it isn't poverty per se but rather poverty combined with lack of access to credit that causes (excessive) child labour. The authors assume parents are altruistic, deriving satisfaction from their children's future consumption. Parents may augment their children's future consumption in two ways, namely, by schooling them so as to raise their future earnings, or by bequeathing them an inheritance. The cost to parents of leaving a bequest is, naturally, reduction in their own consumable resources. Similarly, by schooling their children as opposed to working them, parents forego 
children's earnings from labour. Parents choose an optimal combination of schooling and bequest by, for example, trading-off a quantity of bequest for more schooling. Poverty poses the particular difficulty that poor parents may not have resources to bequeath their children and so there is no question of trading-off a sum of bequest for more schooling, that is, unless it were possible for bequests to take negative values. Therefore, poverty-stricken parents unable to engineer negative bequests, i.e., resource transfers back in time from adult children to parents, may be constrained to educate their children less than they would like. Since child labour is the converse of children's schooling in this model, poverty may, thus, cause child labour to be greater than in an interior solution. Access to credit may alleviate this difficulty by enabling negative bequests. Were children to be relied upon to honour their parents' debts, parents might simply borrow at present to leave their children the negative bequest of debt. Thus, if it were possible for impoverished parents to borrow, work by their children might not be excessive.

Alternatively, parents whose initial endowment is low relative to their children's future earnings may wish to transfer resources from the future to the present. With option to borrow, parents would accomplish this inter-temporal resource transfer by availing of loans upon the strength of their children's future earnings. This is, of course, predicated upon children's willingness to take on their parents' debts, i.e., upon children's altruistic feelings for their parents or 'reverse altruism'. On the other hand, without access to credit, parents may be compelled to effectuate an intertemporal resource transfer by the means of putting their children to work as opposed to schooling them, increasing parents' current consumption at the expense of children's future earnings. Hence, an increase in household access to credit may decrease child labour.

However, this ignores the ramifications of household work wherein the bulk of child labour is engaged. Wydick [1999] makes the rare observation that improved access to credit may increase child labour in household enterprises. By making the purchase of market inputs like capital equipment possible, credit may raise the labour productivity of household children in family enterprises. Given that the poor in many developing countries now often obtain credit in the form of 
microenterprise loans, i.e., loans specifically for purposes of production, improved access to credit may, thus, increase child labour, particularly when hired labour is scarce or when the potential for moral hazard by hired labour is high making hired and household labour poor substitutes in household enterprises [Wydick, 1999].

Even though a relation between access to credit and child labour is amply supported in theory, it has seldom been empirically verified. Dehejia and Gatti [2002] find evidence of a significantly negative cross-country association between child labour and access to credit as measured by the ratio of private credit issued by banks to GDP. Beegle, Dehejia, and Gatti [2003] find that transitory income shocks in the Kagera region of Tanzania lead to increased work by children but that household access to credit, measured by the value of household collateralizable assets, mitigates the increase. Wydick [1999], investigating the effect of microenterprise lending upon child labour in western Guatemala, finds that increased access to credit generally reduces the likelihood of a child being withdrawn from school for the purposes of work in a household enterprise. However, the author discovers that this positive effect of access to credit upon children's schooling is dampened when the nature of the household enterprise raises the potential for moral hazard by hired labour or when credit enables the labour productivity enhancing physical capitalization of the enterprise. Ersado [2002] finds that credit access, measured by the presence in the community of a commercial bank, is likely to improve school enrollment rates while decreasing child labour in rural Nepal and Zimbabwe. Ersado [2002] discovers, however, that proximity to a commercial bank in rural Peru actually increases the probability of children working as against attending school. The author conjectures credit in rural Peru fosters household enterprises employing child labour.

This study seeks to contribute to the meagre body of evidence of a relation between access to credit and child labour in developing countries. It shall allow for the possibility of a positive rather than a negative, or, in the least, of a dampened negative, relation between household access to microcredit and work by children. Further, it shall distinguish between children's domestic chores and work in household enterprises. The finding, for instance, that household access to microcredit is 
positively related to children's domestic work and, in contrast, unrelated to child labor in household enterprises may indicate that only adults are busied in household enterprises following improved access to microcredit whereas children merely replace them in the shouldering of domestic chores. Finally, as will be discussed in section II, this study measures household access to credit in a novel manner as the sum of the self-assessed credit limits of household members at microcredit organizations. It has been argued this is a truer and more exogenous measure of access to microcredit than actual loan uptake or dichotomous membership in a microcredit organization.

A subsidiary goal of this study is examination of trade-off between children's work and schooling in rural Malawi. While a leading objection to work by children is that it may reduce schooling to the detriment of their future welfare and national economic growth, the empirical evidence is ambiguous. For example, Psacharopoulos [1997] uses data from Bolivia and Venezuela to show that children who work are more likely to fail at school and that child work reduces educational attainment by almost two years. In contrast, Patrinos and Psacharopoulos [1997] find that child labour is not detrimental to schooling in Peru. This study shall examine trade-off between children's work and schooling in rural Malawi by estimating the effect of household access to microcredit upon children's propensity to work and, separately, upon their propensity to attend school ${ }^{1}$. The empirical finding, for example, that an increase in access to microcredit reduces children's propensity to work without affecting their propensity to attend school will suggest the extent of trade-off is marginal. Ravallion and Wodon [2000], employing a comparable strategy, uncover evidence of rather weak trade-off between children's work and school attendance in Bangladesh. Other studies, such as those by Rosati and Tzannatos [2002] and Deb and Rosati [2002], discover that a large proportion of children in less developed countries is neither at school nor at work, implying it is not imperative that a child put to work will forego schooling. If more work leads to less leisure and not to less schooling, child labour may not be detrimental to children's future earnings and may, hence, not be a

\footnotetext{
1 This is preferable to treating work by children, a choice variable, as an exogenous determinant of educational outcomes.
} 
means of the inter-temporal transfer of resources, unless leisure and play contribute to human development in ways valued by the labour market.

Empirical analyses reveal that household access to microcredit raises children's propensity to work in rural Malawi. Further, it is found that access to microcredit appears significantly related only to children's household domestic work. Finally, it is found that household access to microcredit has no statistically discernible effect upon children's school attendance.

The remainder of the paper is organized as follows. Section II describes the data from rural Malawi and discusses empirical issues in the measurement of access to credit. Section III presents an econometric model of the relation between work by children and household access to microcredit, and the empirical findings. Section IV summarizes these findings and briefly concludes.

\section{THE DATA}

Data for this study are drawn from the Malawi Financial Markets and Food Security Survey conducted jointly in 1995 by the International Food Policy Research Institute [IFPRI] and the Department of Rural Development $[D R P]$ of the Bunda College of Agriculture of the University of Malawi. A total of 404 rural households in 45 villages of 5 Malawian districts were surveyed. These households did not constitute a random sample. Since it was necessary to include sufficient numbers of microcredit program participants in the survey, stratified random sampling was resorted to such that half of the final sample of 404 households consisted of current microcredit program participants with past participants and non-participants making up approximately equal portions of the remainder. The non-randomness of the sample calls for the inclusion of sampling weights in estimation.

The data are rich in household and community descriptors. Further, time allocation data for seven to eleven year old children were elicited. Children were taken to allocate time between educational, leisure, and work activities. Children's activities of fetching firewood/dung/straw, helping in field/with animals, working at somebody else's for wage/meal, fetching drinking water, 
and other domestic housework, may be considered child work. Of these, the fetching of firewood/dung/straw, the fetching of drinking water, and other domestic housework may be considered children's household domestic work. It may be noted that actual time in an activity was unreported: it is merely known if a child undertook the activity.

The yearlong survey consisted of 3 rounds. The first round was conducted from February to April, the second between July and September, and the third in November and December. The Malawian farming season begins in November. February to April is the period of peak harvest. Demand for child labour is particularly high then, partly because it is believed children are especially adept at plucking tea and tobacco leaf. Further, maize, the Malawian staple, is harvested in April. The months shortly preceding April are, thus, lean months for subsistence-farming households during which children are often compelled to work for wages with which to purchase maize. Indeed, the proportions of children engaging in some type of work, whether in a household enterprise or for wages, in the first, second, and third rounds of the survey were, respectively, 51.7 per cent, 45.3 per cent, and 35.9 per cent. Hence, this study uses data from the first round (February-April) of the survey.

Access to credit, in studies relating it to economic outcomes, has usually been measured in two ways, namely, dichotomous membership in credit programs, and actual loan uptake. Both these measures may be unsuitable for estimating the true causal effect of credit access [David and Meyer, 1980]. First, since credit program participation and loan uptake are voluntary, the measures are potentially endogenous. Parents who avail of loans may be less likely to work their children, but it cannot be concluded that loans reduce child labour since parents more eager to educate their children may be likelier to seek out helpful loans. Second, loan uptake would measure access to credit accurately only if credit limits were universally binding, i.e., if everyone's loan uptake were equivalent to her credit limit. In reality, individuals often do not fully exercise their option to borrow. That option, nonetheless, may influence economic behaviour. For example, households with unexercised option to borrow might, as a result, feel sufficiently secure to embark upon a household enterprise 
employing child labour. Third, membership in a credit program often confers benefits unrelated to credit access such as literacy classes and business training. These secondary effects of credit program participation may confound the true causal effect of access to credit. Finally, mere membership in a credit program may not guarantee ready access to credit. Indeed, many group-based credit programs stipulate that only half of a group's members may receive credit at any time. Even credit programs repudiating this rule rarely provide their members with assured access to credit.

Hence, Diagne [1998] and Diagne and Zeller [2001] argue that the credit limit, the maximum amount that may be borrowed as self-reported by survey participants, is a better measure of credit access. The authors reason that unlike credit program participation or loan uptake, which are related to demand for credit, the credit limit, reflecting mainly supply-side factors such as the availability of credit programs and the financial resources of lenders, is a truer measure of an exogenous credit constraint. Therefore, the Malawi Financial Markets and Food Security Survey having queried respondents over 17 years of age about the maximum amount they might conceivably have borrowed, this study shall measure a household's access to microcredit by the sum of the selfassessed credit limits of its members at microcredit organizations such as those described below. Malawi has four main credit and savings programs: the Malawi Rural Finance Company [MRFC], Promotion of Micro-Enterprises for Rural Women [PMERW], the Malawi Mudzi Fund $[M M F]$, and the Malawi Union of Savings and Credit Cooperatives [MUSCCO]. The first three are group-lending programs, whereas MUSCCO is an individual membership based union organization. MRFC and MUSCCO provide seasonal agricultural credit, mainly to tobacco and maize farmers. PMERW and MMF, operating in but a few districts, specialize in off-farm credit, though a portion of MMF's loan portfolio supports agricultural operations. In addition, there are numerous small credit programs run by NGOs and foreign government organizations. 


\section{ECONOMETRIC MODEL AND EMPIRICAL FINDINGS}

Improvement in access to credit is taken to relax the working capital constraints of household production. It is held, however, that resources allocated to household production may increase by more than the actual sums borrowed. In fact, more resources may be allocated to household production even if no borrowing occurs. For example, given uncertainty, a household with greater access to credit may, with loans to fall back upon, be likelier to use precautionary savings to purchase inputs. The mere option to borrow, then, may raise a household's working capital.

Wydick [1999] predicts two effects of an increase in working capital upon a household's employment of its children: the 'family-labour -substitution effect' and the 'household-enterprisecapitalization effect'. Working capital would permit the replacement of family labour in household enterprises by hired labour. Thus, the 'family-labour -substitution effect' makes for a negative relation between resources allocated to household production and child labour employed therein. However, the effect would be diminished if hired labour were either a poor substitute for family labour or in short supply. For example, Wydick [1999] contends that households may find hired labour an inadequate substitute for family labour in retail sales enterprises given opportunities for petty theft. The 'household-enterprise-capitalization effect', on the other hand, pertains to the increase in the marginal productivity of child labour in household enterprises from the increase in purchased inputs that additional working capital enables. This makes for a positive relation between working capital and child labour in household enterprises. Thus, the net effect of household access to credit upon child labour depends upon the relative magnitudes of the mutually opposed 'family-labour substitution effect' and 'household-enterprise-capitalization effect'.

The above motivates an econometric model of child labour that may be specified simply as

$$
H^{*}=X^{\prime} \beta+u,
$$

where $H^{*}$ denotes a child's optimal work hours, $X$ indicates a vector of correlates that includes a measure of household access to credit and interactions that capture the 'family-labour-substitution effect' and 'household-enterprise-capitalization effect', and $u$, the error term, represents unobserved 
random influences. Given that work by children in the Malawi Financial Markets and Food Security Survey is measurable only as a dichotomous variable, $H^{*}$ may be considered the latent variable underlying a binary $H$ such that $H=1$ if $H^{*}>0, H=0$ otherwise. Assuming the error term, $u$, is normally distributed, (1) may be estimated by probit ML.

Estimates of the coefficients of the twin equations

$$
H_{1}^{*}=X^{\prime} \beta_{1}+u_{1}
$$

and

$$
H_{2}^{*}=X^{\prime} \beta_{2}+u_{2}
$$

where $H_{1}{ }^{*}$ and $H_{2}{ }^{*}$ denote a child's optimal work hours in domestic chores and in household enterprises, respectively, would shed light upon whether household access to microcredit influences these two types of child work differently. Since $H_{1}{ }^{*}$ and $H_{2}{ }^{*}$ are observed but dichotomously, assuming the errors $u_{1}$ and $u_{2}$ are bivariate-normally distributed, (2) and (3) may be jointly estimated by bivariate probit ML.

Finally, estimates of the coefficients of the equation

$$
S^{*}=X^{\prime} \gamma+v,
$$

where $S^{*}$ denotes a child's optimal hours in school and $v$, the error term, would reveal whether access to microcredit is correlated with school attendance in rural Malawi. Since school attendance too is reported but dichotomously in the Malawi Financial Markets and Food Security Survey, (4) may, assuming the error $v$ is normally distributed, be estimated by probit ML.

Table 1 presents the sample means of all utilized variables. Of the 261 seven to eleven year old children examined, 51.7 per cent worked in the two days preceding their interview. 42.9 per cent of children undertook domestic chores, and 11.1 per cent worked in a household enterprise. No child in the sample worked at somebody else's for pay. 16.9 per cent visited school in the two days preceding their interview. On the other hand, 74.7 per cent of the sampled children attended school during the last school year. It is unclear why there is this marked discrepancy between school attendance in the two days preceding a visit by surveyors and that in the past school year. Average 
age in the sample is near 9 years. Girls constituted about 48 per cent of the sample. Sample mean household access to microcredit stands at 972.9 Malawi Kwacha².

Table 2 presents probit estimates of (1). As discussed, the non-random nature of sampling in the Malawi Financial Markets and Food Security Survey necessitates the inclusion of sampling weights in estimation. Further, standard errors are adjusted for the multiplicity of children per household since it is likely such clustering vitiates the independence of error terms across children. It appears girls are significantly more likely to work than boys in rural Malawi. It is plausible this is indicative of intra-household gender inequity. The probability of child work declines significantly in household size. It is supposable that household size measures the combined availability of family labour, and is, therefore, negatively related to the probability of an individual child being called upon to work. The probability of work increases significantly in the number of younger children. This is not surprising given children must often assist in the rearing of younger siblings. Controlling for measures of household wage labour income and wealth, children appear significantly less likely to work in female-headed households. This is consistent with the increasingly popular view that intrahousehold resource allocation results from bargaining between parents, so that, given the nature of maternal solicitude, there is a positive relation between female empowerment and children's well being. The probability of child work declines significantly in household wage labour income, in household landholding, and in the number of retail sales enterprises. These are plausibly in the nature of wealth effects.

Three village attributes, namely, the presence of a primary and a secondary school, and the proportion of village households with relatively large landholdings, are included as regressors. The former two variables measure local access to schooling. The third attempts to measure the local availability of labour for hire, since the supply of labour to market plausibly decreases in household landholding. Hence, it is expected that the greater the proportion of village households with relatively large landholdings, the smaller the local supply of labour for hire, with consequences for the

${ }^{2}$ Recall this study measures a household's access to microcredit by the sum of the self-assessed credit limits of its members at microcredit 
employment of family child labour in household production. However, none of these variables is a significant correlate of children's propensity to work.

The share of acreage under major crops devoted to tobacco is included as a regressor given that tobacco cultivation is highly labour intensive and that it is widely believed children are particularly adept at plucking tobacco leaf. The variable, however, is found to be statistically insignificant.

The interaction 'Household access to microcredit x Area owned land in acres' endeavours to identify the 'household-enterprise-capitalization effect', i.e., the increased employment of family child labour in household enterprises due to the labour productivity enhancing increases in purchased inputs that additional working capital enables. Farming is the primary occupation of 66 per cent of household heads in the Malawi Financial Markets and Food Security Survey [Diagne and Zeller, 2001], which suggests farming is the commonest household enterprise in rural Malawi. It is plausible that the increase in labour productivity on family farms from an increase in purchased inputs would be more pronounced the greater the input of land. Hence, the interaction of household access to microcredit and household landholding is expected to be positively correlated with children's propensity to work ${ }^{3}$.

The interactions 'Household access to microcredit x Number of retail sales enterprises' and 'Household access to microcredit x Proportion of village households owning +5 acres of land' relate to the 'family-labour-substitution effect'. While working capital facilitates the substitution of hired for family labour in household enterprises, substitution would be hindered by the imperfect substitutability of hired for family labour in, e.g., retail sales enterprises, and by a shortage of labour for hire. Thus, these interactions are expected to be positively correlated with children's propensity to work.

organizations.

${ }^{3}$ Wydick [1999], on the other hand, attempts to capture the 'household-enterprise-capitalization effect' rather directly by including, as a determinant of work by children, an indicator of whether borrowed monies were used to purchase capital equipment. However, given enterprises make labour and capital input decisions simultaneously, it is likely the indicator variable is endogenous. 
By the probit estimates in table 2 , access to microcredit significantly reduces the probability of child work in households without land or retail sales enterprises. However, when combined with the sample means in table 1, the estimates indicate that a unit increase in access to microcredit raises the probability of child work in households with sample mean values of 'area owned land in acres' and 'number of retail sales enterprises', in that $-0.079+0.015 \times 5.520+0.043 \times 0.371=0.178>0$. This is a notable finding given that 100 per cent and 31 per cent of the sampled children resided in, respectively, households owning land and operating retail sales enterprises. That the coefficient of the interaction 'Household access to microcredit x Area owned land in acres' is positive with the variable significant is interpretable as evidence of the 'household-enterprise-capitalization effect'. Further, that the coefficient of the interaction 'Household access to microcredit x Number of retail sales enterprises' is positive with the variable significant suggests the substitution of hired for family labour by the 'family-labour substitution effect' is impeded when the two types of labour are imperfect substitutes. The interaction 'Household access to microcredit x Proportion of village households owning +5 acres of land' is found to be insignificant.

Table 3 presents bivariate probit estimates of (2) and (3). Girls are significantly more likely than boys to be put to domestic work. The probability of child domestic work decreases in household size and increases in the number of younger siblings. Children appear less likely to perform domestic chores in households headed by women. Further, the older the household head, the lower the probability of child domestic work. The probability of child domestic work decreases significantly in household wage labour income, in household landholding, and in the value of household assets other than land, livestock, and food stocks. On the other hand, girls are significantly less likely than boys to work in a household enterprise. The probability of child work in a household enterprise decreases in the value of household landholding. It increases in the share of acreage under major crops devoted to tobacco, as well as in the number of household retail sales enterprises. The probability of child work in a household enterprise increases in the proportion of village households with relatively large landholdings. This stands to reason if the availability of labour for hire is 
negatively related to the proportion of village households with relatively large landholdings. Lastly, children in villages with a primary school and a secondary school are significantly less likely to work in a household enterprise.

It is notable that household access to microcredit significantly raises the probability of child domestic work in households either owning land or operating retail sales enterprises. That, on the other hand, access to microcredit or its interactions aren't statistically significant correlates of children's work in a household enterprise suggests that child work in households either owning land or operating retail sales enterprises is affected only to the extent that children must relieve adults of domestic chores as the latter are busied in household enterprises following improved access to microcredit.

Table 4 presents probit estimates, expected to shed light upon trade-off between children's work and schooling in rural Malawi, of (4). Briefly, household access to microcredit and its interactions are found to be statistically insignificant correlates of children's propensity to attend to school. This suggests trade-off between children's work and schooling is marginal, since, in contrast, by the estimates in table 2 , household access to microcredit and two of its three included interactions are statistically significant correlates of children's propensity to work. Perhaps, as argued by Ravallion and Wodon [2000], trade-off between children's work and schooling is greatly tempered by children's leisure absorbing the effect of the one upon the other, i.e., by more work leading to less leisure rather than to less schooling.

\section{CONCLUSION}

This study seeks to estimate the causal effect of household access to microcredit, measured in a novel manner as self-assessed credit limits at microcredit organizations, upon children's propensity to work in rural Malawi. This measure of access to credit, it has been argued [Diagne, 1998, Diagne and Zeller, 2001], is a truer, more exogenous, measure than actual loan uptake or dichotomous credit program participation. Whereas both consumer and microenterprise loans raise household current 
consumption, consumer loans achieve this directly whereas microenterprise loans realizes this but indirectly, by promoting family enterprises employing household members including children. Hence, this study aims to discover whether access to microcredit might increase rather than decrease child work,

It is found that children's propensity to work in rural Malawi, computed at sample mean values of household land ownership and number of retail sales enterprises, increases in household access to microcredit. It is indicated that this is due to children having to take up more domestic chores as adults are busied in household enterprises following improved access to microcredit. However, household access to microcredit and its interactions are found to be statistically insignificant correlates of children's propensity to attend school, suggesting work by children reduces school attendance by little.

While microenterprise loans are deservedly credited with improving the lives of large numbers of the world's poor, this paper's findings indicate that they may cause children to be drawn into credit-stimulated household work. However, given that children's leisure may temper trade-off between their work and schooling, children's school attendance may not suffer. Still, child development specialists might consider children's loss of leisure a weighty negative consequence of the burgeoning of microcredit organizations. 
TABLE 1

DESCRIPTIVE STATISTICS

\begin{tabular}{|c|c|c|}
\hline Variable & Mean & S.D. \\
\hline \multicolumn{3}{|l|}{ Dependent Variables } \\
\hline Worked in 2 days preceding interview & 0.517 & 0.501 \\
\hline Performed household domestic chores in 2 days preceding interview & 0.429 & 0.496 \\
\hline Worked in a household enterprise in 2 days preceding interview & 0.111 & 0.315 \\
\hline Attended school in 2 days preceding interview & 0.169 & 0.375 \\
\hline Attended school in last school year & 0.747 & 0.435 \\
\hline \multicolumn{3}{|l|}{ Child Attributes } \\
\hline Female & 0.479 & 0.501 \\
\hline Age in years & 8.816 & 1.453 \\
\hline \multicolumn{3}{|l|}{ Household Attributes } \\
\hline Number of members & 6.824 & 2.309 \\
\hline Number of $0-6$ year-old members & 1.307 & 1.142 \\
\hline Number of 7-11 year-old members & 1.783 & 0.857 \\
\hline Household head's age in years & 45.393 & 11.753 \\
\hline Female household head & 0.285 & 0.452 \\
\hline Total wage labour income of +17 year-old members, in hundreds of Malawi & 1.726 & 6.688 \\
\hline \multicolumn{3}{|l|}{ Kwacha (MK), since October 1994} \\
\hline Area owned land in acres & 5.520 & 7.730 \\
\hline Value, in thousands of MK, of owned land & 5.852 & 25.270 \\
\hline Value, in thousands of $\mathrm{MK}$, of assets other than land, livestock, and food stocks & 4.181 & 12.163 \\
\hline Share of acreage under major crops devoted to tobacco & 0.049 & 0.141 \\
\hline Number of retail sales enterprises & 0.371 & 0.614 \\
\hline \multicolumn{3}{|l|}{ Village Attributes } \\
\hline Proportion of village households owning +5 acres of land & 0.061 & 0.084 \\
\hline Primary school present & 0.461 & 0.499 \\
\hline Secondary school present & 0.049 & 0.216 \\
\hline \multicolumn{3}{|l|}{ Key Variables } \\
\hline Household access to microcredit in hundreds of MK & 9.729 & 20.055 \\
\hline Household access to microcredit $\mathrm{x}$ Area owned land in acres & 99.603 & 661.460 \\
\hline Household access to microcredit $\mathrm{x}$ Number of retail sales enterprises & 5.336 & 19.528 \\
\hline $\begin{array}{l}\text { Household access to microcredit x Proportion of village households owning }+5 \\
\text { acres of land }\end{array}$ & 0.998 & 5.035 \\
\hline $\mathrm{n}=$ & & 261 \\
\hline
\end{tabular}


TABLE 2

DETERMINANTS OF WORK BY CHILDREN: PROBIT ESTIMATES

\begin{tabular}{|c|c|c|}
\hline Variable & Coefficient & T-ratio \\
\hline Constant & 1.489 & 1.49 \\
\hline \multicolumn{3}{|l|}{ Child Attributes } \\
\hline Female & $0.928^{* * *}$ & 3.65 \\
\hline Age in years & 0.242 & 1.63 \\
\hline \multicolumn{3}{|l|}{ Household Attributes } \\
\hline Number of members & $-0.479 * * *$ & -3.37 \\
\hline Number of 0-6 year-old members & $0.563^{* * *}$ & 2.74 \\
\hline Number of $7-11$ year-old members & 0.248 & 0.99 \\
\hline Household head's age in years & -0.015 & -1.18 \\
\hline Female household head & $-0.952 * * *$ & -2.67 \\
\hline Total wage labour income of +17 year-old members, in hundreds of Malawi & $-0.033 * * *$ & -2.86 \\
\hline \multicolumn{3}{|l|}{ Kwacha (MK), since October 1994} \\
\hline Area owned land in acres & $-0.118 * * *$ & -2.63 \\
\hline Value, in thousands of MK, of owned land & -0.066 & -1.41 \\
\hline Value, in thousands of MK, of assets other than land, livestock, and food stocks & -0.021 & -0.61 \\
\hline Share of acreage under major crops devoted to tobacco & 1.924 & 1.61 \\
\hline Number of retail sales enterprises & $-0.572 * *$ & -2.54 \\
\hline \multicolumn{3}{|l|}{ Village Attributes } \\
\hline Proportion of village households owning +5 acres of land & -3.655 & -1.21 \\
\hline Primary school present & 0.220 & 0.83 \\
\hline Secondary school present & -0.175 & -0.36 \\
\hline \multicolumn{3}{|l|}{ Key Variables } \\
\hline Household access to microcredit in hundreds of MK & $-0.079 * * *$ & -2.59 \\
\hline Household access to microcredit $\mathrm{x}$ Area owned land in acres & $0.015^{* * *}$ & 3.70 \\
\hline Household access to microcredit $\mathrm{x}$ Number of retail sales enterprises & $0.043^{* * *}$ & 2.88 \\
\hline $\begin{array}{l}\text { Household access to microcredit x Proportion of village households owning }+5 \\
\text { acres of land }\end{array}$ & 0.308 & 1.25 \\
\hline Log-likelihood & \multicolumn{2}{|c|}{-127.879} \\
\hline
\end{tabular}

Note: $* * *$, and ${ }^{* * *}$ denote, respectively, significance at the $10 \%, 5 \%$, and $1 \%$ levels 
TABLE 3

DETERMINANTS OF DOMESTIC AND OTHER WORK BY CHILDREN

\begin{tabular}{|c|c|c|c|c|}
\hline Variable & Coefficient & T-ratio & Coefficient & T-ratio \\
\hline & \multicolumn{2}{|c|}{ Domestic Work } & \multicolumn{2}{|c|}{ Work in an Enterprise } \\
\hline Constant & 0.989 & 0.92 & -0.564 & $-0.40^{1}$ \\
\hline \multicolumn{5}{|l|}{ Child Attributes } \\
\hline Female & $1.158^{* * *}$ & 4.26 & $-0.716^{*}$ & -1.91 \\
\hline Age in years & 0.249 & 1.63 & 0.012 & 0.08 \\
\hline \multicolumn{5}{|l|}{ Household Attributes } \\
\hline Number of members & $-0.312^{* * *}$ & -2.77 & -0.177 & -1.18 \\
\hline Number of $0-6$ year-old members & $0.418^{* *}$ & 2.25 & 0.165 & 0.79 \\
\hline Number of $7-11$ year-old members & 0.232 & 1.03 & -0.261 & -0.79 \\
\hline Household head's age in years & $-0.037 * * *$ & -3.20 & 0.017 & 1.08 \\
\hline Female household head & $-1.115^{* * *}$ & -3.46 & 0.387 & 1.21 \\
\hline $\begin{array}{l}\text { Total wage labour income of }+17 \text { year-old } \\
\text { members, in hundreds of Malawi Kwacha } \\
(\mathrm{MK}) \text {, since October } 1994\end{array}$ & $-0.035^{* *}$ & -2.24 & -0.009 & -0.88 \\
\hline Area owned land in acres & $-0.091 * *$ & -2.10 & 0.004 & 0.09 \\
\hline Value, in thousands of MK, of owned land & -0.006 & -0.012 & $-0.182^{*}$ & 1.88 \\
\hline $\begin{array}{l}\text { Value, in thousands of MK, of assets other } \\
\text { than land, livestock, and food stocks }\end{array}$ & $-0.094 *$ & -1.67 & 0.027 & 1.26 \\
\hline $\begin{array}{l}\text { Share of acreage under major crops } \\
\text { devoted to tobacco }\end{array}$ & 1.419 & 1.37 & $1.665^{*}$ & 1.66 \\
\hline $\begin{array}{l}\text { Number of retail sales enterprises } \\
\text { Village Attributes }\end{array}$ & -0.665 & -2.47 & $0.657^{* *}$ & 2.04 \\
\hline $\begin{array}{l}\text { Proportion of village households owning } \\
+5 \text { acres of land }\end{array}$ & -1.915 & -0.71 & $4.273^{*}$ & 1.80 \\
\hline Primary school present & 0.395 & 1.59 & $-0.619 * *$ & -2.08 \\
\hline $\begin{array}{l}\text { Secondary school present } \\
\text { Key Variables }\end{array}$ & -0.003 & -0.005 & $-5.779 * * *$ & -12.91 \\
\hline $\begin{array}{l}\text { Household access to microcredit in } \\
\text { hundreds of MK }\end{array}$ & -0.036 & -1.10 & -0.017 & -0.56 \\
\hline $\begin{array}{l}\text { Household access to microcredit x Area } \\
\text { owned land in acres }\end{array}$ & $0.007 * *$ & 2.41 & 0.0002 & 0.06 \\
\hline $\begin{array}{l}\text { Household access to microcredit } x \\
\text { Number of retail sales enterprises }\end{array}$ & $0.044 * *$ & 2.38 & -0.020 & -0.57 \\
\hline $\begin{array}{l}\text { Household access to microcredit } x \\
\text { Proportion of village households owning } \\
+5 \text { acres of land }\end{array}$ & -0.207 & -1.14 & 0.058 & 0.39 \\
\hline Log-likelihood & & & -149.442 & \\
\hline
\end{tabular}

Note: $*$, **, and $* * *$ denote, respectively, significance at the $10 \%, 5 \%$, and $1 \%$ levels 
TABLE 4

DETERMINANTS OF CHILDREN'S SCHOOL AT'TENDANCE

Dependent Variable $=$ Attended school in 2 days preceding interview; Probit Estimates

\begin{tabular}{|c|c|c|c|c|}
\hline Variable & Coefficient & T-ratio & Coefficient & T-ratio \\
\hline & \multicolumn{2}{|c|}{ In 2 days before interview } & \multicolumn{2}{|c|}{ In the last school year } \\
\hline Constant & $-3.056 * * *$ & -3.15 & $-3.203 * * *$ & -2.87 \\
\hline \multicolumn{5}{|l|}{ Child Attributes } \\
\hline Female & -0.484 & -1.43 & -0.309 & -1.15 \\
\hline Age in years & $0.213^{* * *}$ & 3.00 & $0.261 * * *$ & 3.18 \\
\hline \multicolumn{5}{|l|}{ Household Attributes } \\
\hline Number of members & 0.167 & 1.04 & -0.165 & -1.10 \\
\hline Number of $0-6$ year-old members & -0.029 & -0.11 & 0.221 & 0.99 \\
\hline Number of 7-11 year-old members & 0.096 & 0.37 & $0.509 *$ & 1.81 \\
\hline Household head's age in years & -0.009 & -0.46 & $0.029 *$ & 1.77 \\
\hline Female household head & -0.417 & -0.90 & -0.102 & -0.28 \\
\hline $\begin{array}{l}\text { Total wage labour income of }+17 \text { year-old } \\
\text { members, in hundreds of Malawi Kwacha } \\
\text { (MK), since October } 1994\end{array}$ & -0.008 & -0.86 & $-0.027 *$ & -1.81 \\
\hline Area owned land in acres & -0.016 & -0.32 & -0.022 & -0.50 \\
\hline Value, in thousands of MK, of owned land & 0.006 & 0.32 & 0.067 & 1.32 \\
\hline $\begin{array}{l}\text { Value, in thousands of MK, of assets other } \\
\text { than land, livestock, and food stocks }\end{array}$ & 0.006 & 0.18 & -0.017 & -0.61 \\
\hline $\begin{array}{l}\text { Share of acreage under major crops } \\
\text { devoted to tobacco }\end{array}$ & -0.450 & -0.41 & -0.022 & -0.02 \\
\hline $\begin{array}{l}\text { Number of retail sales enterprises } \\
\text { Village Attributes }\end{array}$ & 0.123 & 0.29 & -0.650 & -1.64 \\
\hline $\begin{array}{l}\text { Proportion of village households owning } \\
+5 \text { acres of land }\end{array}$ & $-7.429 * *$ & -2.54 & 3.350 & 1.32 \\
\hline Primary school present & -0.284 & -0.67 & 0.350 & 0.93 \\
\hline $\begin{array}{l}\text { Secondary school present } \\
\text { Key Variables }\end{array}$ & -3.589 & -0.66 & $1.488^{* *}$ & 2.40 \\
\hline $\begin{array}{l}\text { Household access to microcredit in } \\
\text { hundreds of MK }\end{array}$ & -0.020 & -0.51 & 0.001 & 0.04 \\
\hline $\begin{array}{l}\text { Household access to microcredit x Area } \\
\text { owned land in acres }\end{array}$ & 0.0002 & 0.26 & 0.003 & 1.07 \\
\hline $\begin{array}{l}\text { Household access to microcredit } \mathrm{x} \\
\text { Number of retail sales enterprises }\end{array}$ & 0.025 & 0.61 & 0.048 & 1.21 \\
\hline $\begin{array}{l}\text { Household access to microcredit } x \\
\text { Proportion of village households owning } \\
+5 \text { acres of land }\end{array}$ & 0.082 & 0.67 & -0.170 & -1.19 \\
\hline Log-likelihood & & & & 162 \\
\hline
\end{tabular}

Note: $* * *$, and $* * *$ denote, respectively, significance at the $10 \%, 5 \%$, and $1 \%$ levels 


\section{REFERENCES}

Baland, J. M. and J. A. Robinson, 2000, 'Is Child Labour Inefficient?', Journal of Political Economy, Vol. 108, No. 4, pp. 662-679.

Beegle, K., R. H. Dehejia, and R. Gatti, 2003, 'Child Labour, Crop Shocks, and Credit Constraints', NBER Working Paper No. W10088, Cambridge: National Bureau of Economic Research.

Basu, K. and P. H. Van, 1998, 'The Economics of Child Labour', American Economic Review, Vol. 88, No. 3, pp. 412-27.

Binder, M. and D. Scrogin, 1999, 'Labour Force Participation and Household Work of Urban Schoolchildren in Mexico: Characteristics and Consequences', Economic Development and Cultural Change, Vol. 48, No. 1, pp. 123-54.

David, C. and W. Meyer, 1980, 'Measuring the Farm Level Impact of Agricultural Loans in Low Income Countries: A Review Article', in J. Howell (ed.), Borrowers and Lenders: Rural Financial Markets and Institutions in Developing Countries, London: Overseas Development Institute.

Deb, P. and R. Rosati, 2002, 'Determinants of Child Labour and School Attendance: The Role of Household Unobservables', Hunter College Department of Economics Working Paper No. 02/9, New York: Department of Economics, Hunter College.

Dehejia, R. H. and R. Gatti, 2002, 'Child Labour: The Role of Income Variability and Access to Credit Across Countries', NBER Working Paper No. W9018, Cambridge: National Bureau of Economic Research.

Diagne, A., 1998, 'Impact of Access to Credit on Income and Food Security in Malawi', IFPRI Discussion Paper No. 46, Washington, D.C.: International Food Policy Research Institute. Diagne, A. and M. Zeller, 2001, 'Access to Credit and its Impact on Welfare in Malawi', IFPRI Research Report No. 116, Washington, D.C.: International Food Policy Research Institute. Ersado, Lire, 2002, 'Child Labour and School Decisions in Urban and Rural Areas: Cross Country Evidence', IFPRI Discussion Paper No. 145, Washington, D.C.: International Food Policy Research Institute. 
ILO, 1996, A, Economically Active Populations, 1950-2010, Fourth Edition, Geneva: International Labour Office.

ILO, 1996, B, 'Child Labour: What is to be done?’, Document for Discussion at the Informal Tripartite Meeting at the Ministerial Level, Geneva: ILO.

ILO, 1998, A, 'Child Labour: Targeting the Intolerable', 86 $6^{\text {th }}$ Session, International Labour Conference, Geneva: International Labour Office.

ILO, 1998, B, 'Child Labour in Africa: Targeting the Intolerable', African Regional Tripartite Meeting on Child Labour, Geneva: International Labour Office.

Nieuwenhuys, O., 1994, Children's Lifeworlds, London and New York: Routledge Press.

Patrinos, H. A. and G. Psacharopoulos, 1997, 'Family Size, Schooling and Child Labour in Peru - An Empirical Analysis', Journal of Population Economics, Vol. 10, No. 4, pp. 387-405.

Psacharopoulos, G., 1997, 'Child Labour Versus Educational Attainment: Some Evidence from Latin America', Journal of Population Economics, Vol. 10, No. 4, pp. 377-86.

Ravallion, M. and Q. Wodon, 2000, 'Does Child Labour Displace Schooling? Evidence on Behavioural Responses to an Enrollment Subsidy', The Economic Journal, Vol. 110, No. 462, pp. C158-75.

Rosati, F. and Z. Tzannatos, 2002. 'Child Labour in Vietnam', mimeo, Rome: Universita di Roma. Wydick, B., 1999, 'The Effect of Microenterprise Lending on Child Schooling in Guatemala', Economic Development and Cultural Change, Vol. 47, No. 4, pp. 853-69. 